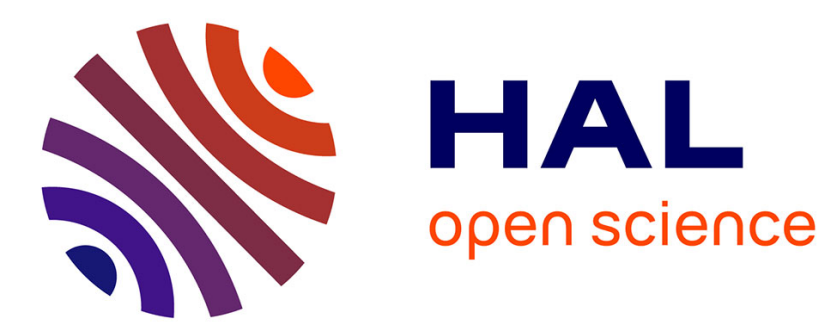

\title{
Longirostrine crocodylians from the Bartonian of Morocco and Paleogene climatic and sea level oscillations in the Peri-Tethys area
}

\author{
Stéphane Jouve, Bouziane Khalloufi, Samir Zouhri
}

\section{To cite this version:}

Stéphane Jouve, Bouziane Khalloufi, Samir Zouhri. Longirostrine crocodylians from the Bartonian of Morocco and Paleogene climatic and sea level oscillations in the Peri-Tethys area. Journal of Vertebrate Paleontology, 2019, pp.e1617723. 10.1080/02724634.2019.1617723 . hal-02182494

\section{HAL Id: hal-02182494 \\ https://hal.sorbonne-universite.fr/hal-02182494}

Submitted on 12 Jul 2019

HAL is a multi-disciplinary open access archive for the deposit and dissemination of scientific research documents, whether they are published or not. The documents may come from teaching and research institutions in France or abroad, or from public or private research centers.
L'archive ouverte pluridisciplinaire HAL, est destinée au dépôt et à la diffusion de documents scientifiques de niveau recherche, publiés ou non, émanant des établissements d'enseignement et de recherche français ou étrangers, des laboratoires publics ou privés. 


\section{Longirostrine crocodylians from the Bartonian of Morocco and Paleogene climatic and sea level oscillations in the Peri-Tethys area}

\section{Stéphane Jouve, Bouziane Khalloufi \& Samir Zouhri}

To cite this article: Stéphane Jouve, Bouziane Khalloufi \& Samir Zouhri (2019): Longirostrine crocodylians from the Bartonian of Morocco and Paleogene climatic and sea level oscillations in the Peri-Tethys area, Journal of Vertebrate Paleontology, DOI: 10.1080/02724634.2019.1617723

To link to this article: https://doi.org/10.1080/02724634.2019.1617723

View supplementary material ¿

Published online: 19 Jun 2019.

Submit your article to this journal $₫$

Џll Article views: 640

View Crossmark data $\asymp$ 


\title{
LONGIROSTRINE CROCODYLIANS FROM THE BARTONIAN OF MOROCCO AND PALEOGENE CLIMATIC AND SEA LEVEL OSCILLATIONS IN THE PERI-TETHYS AREA
}

\author{
STÉPHANE JOUVE, (10,1 BOUZIANE KHALLOUFI, ${ }^{2}$ and SAMIR ZOUHRI ${ }^{3}$ \\ ${ }^{1}$ Centre de Recherches en Paléontologie - Paris, Sorbonne Université, Muséum national d'Histoire naturelle, CR2P, F-75252 Paris \\ Cedex 05, France, jouvestephane@yahoo.fr; \\ ${ }^{2}$ Laboratoire Informatique et Systématique, Sorbonne Université, UMR 7205, Muséum national d'Histoire naturelle, Paris, France, \\ khalloufi.bouziane@hotmail.fr; \\ ${ }^{3}$ Department of Geology, Faculty of Science Aïn Chock, Hassan II University of Casablanca, Casablanca, Morocco, \\ samir.zouhri@univh2c.ma
}

\begin{abstract}
The Eocene-Oligocene transition was a period of high faunal and floral turnover, often correlated with climatic deterioration. Crocodyliforms are climate sensitive, and they have been often used for reconstruction of paleoclimates. The description of crocodylian material from the Bartonian of Aaiun-Tarfaya Basin (Morocco) allows the recognition of at least two longirostrine crocodylians, including a gavialoid. This identification is important, because the migration of gavialoids to South America probably occurred during the late Eocene. Close relationships between late Eocene-early Oligocene Eogavialis africanum from Egypt, Argochampsa krebsi from the Paleocene of Morocco, and the South American gavialoid clade suggests that Morocco could have had a particular place in the gavialoid dispersal route to South America. The resemblance between Moroccan material described herein and E. africanum is thus important in this context. Analysis of the distribution of longirostrine crocodylians in the Peri-Tethys area through the Eocene-Oligocene shows a strong difference in the evolution of the distribution between longirostrine crocodylians and Diplocynodon. Whereas the freshwater Diplocynodon has a continuous distribution in western Europe, the mainly marine longirostrine crocodylians have a northern maximal expansion that moves southward during the middle Eocene, being restricted to North Africa during late Eocene-early Oligocene. European freshwater Asiatosuchus-like taxa also disappear during the late Eocene. Climatic deterioration, helped by sea level oscillations, may have strongly impacted the diversity and latitudinal distribution of the crocodylians, but we highlight a possible differential tolerance in range of climatic conditions between crocodylians. This could help to refine the use of crocodylians as paleoclimatic proxies.
\end{abstract}

\section{SUPPLEMENTAL DATA - Supplemental materials are available for this article for free at www.tandfonline.com/UJVP}

Citation for this article: Jouve, S., B. Khalloufi, and S. Zouhri. 2019. Longirostrine crocodylians from the Bartonian of Morocco and Paleogene climatic and sea level oscillations in the Peri-Tethys area. Journal of Vertebrate Paleontology. DOI: 10.1080/ 02724634.2019 .1617723 .

\section{INTRODUCTION}

The Eocene-Oligocene transition is a period of high terrestrial and marine turnover related to global climate deterioration (e.g., Stehlin, 1909; Houben et al., 2012; Goldner et al., 2014). Crocodyliforms have been recognized as good climatic proxies (Markwick, 1998a, 1998b; Carvalho et al., 2010; Mannion et al., 2015). Knowledge of the late Eocene fossil record makes it possible to document the impact of global climate cooling on the evolutionary and biogeographic histories of crocodyliform faunas. They have been poorly studied in the context of the Eocene-Oligocene crisis.

For two decades, numerous crocodyliforms have been described from the Paleogene of Morocco, particularly from the phosphatic layers of the Oulad Abdoun Basin (see Bardet et al., 2017, for an overview). Because the youngest level providing fossils of vertebrates in this basin is Ypresian, no younger crocodylians are known in the Paleogene of Morocco. Crocodylian remains are scare in North Africa during this period, but the Paleogene is a key period in the history of the longirostrine

*Corresponding author.

Color versions of one or more of the figures in the article can be found online at www.tandfonline.com/ujvp. crocodylians. The oldest known and most primitive tomistomine, Maroccosuchus zennaroi Jonet and Wouters, 1977 (Jouve et al., 2014), has been found in Moroccan Ypresian layers, and gavialoids probably dispersed from the Peri-Tethys area to South America during this time interval. Late Eocene longirostrine crocodylians from Morocco have thus a particular importance in space and time.

The present paper provides a complete description of remains of longirostrine crocodylians from the Bartonian of southern Morocco. It discusses the evolution of crocodylians through the Eocene-Oligocene transition and tentatively provides a hypothesis regarding variations in their distribution and diversity.

Institutional Abbreviation-FSAC, Faculty of Science Aïn Chock, Hassan II University of Casablanca, Casablanca, Morocco.

\section{LOCATION AND GEOLOGICAL CONTEXT}

The material described herein comes from Gueran, also called Guerran, Garouan, Punta Güeran, and Krebb Afedeira (Fig. 1). The field is located approximately $125 \mathrm{~km}$ southeast of Boujdour, in an uninhabited depression in the Sahara Desert of southern Morocco, and pertains to the Aaiun-Tarfaya Basin (also called Tarfaya-Laayoun-Dakhla Basin or Boujdour Basin) (Ranke 


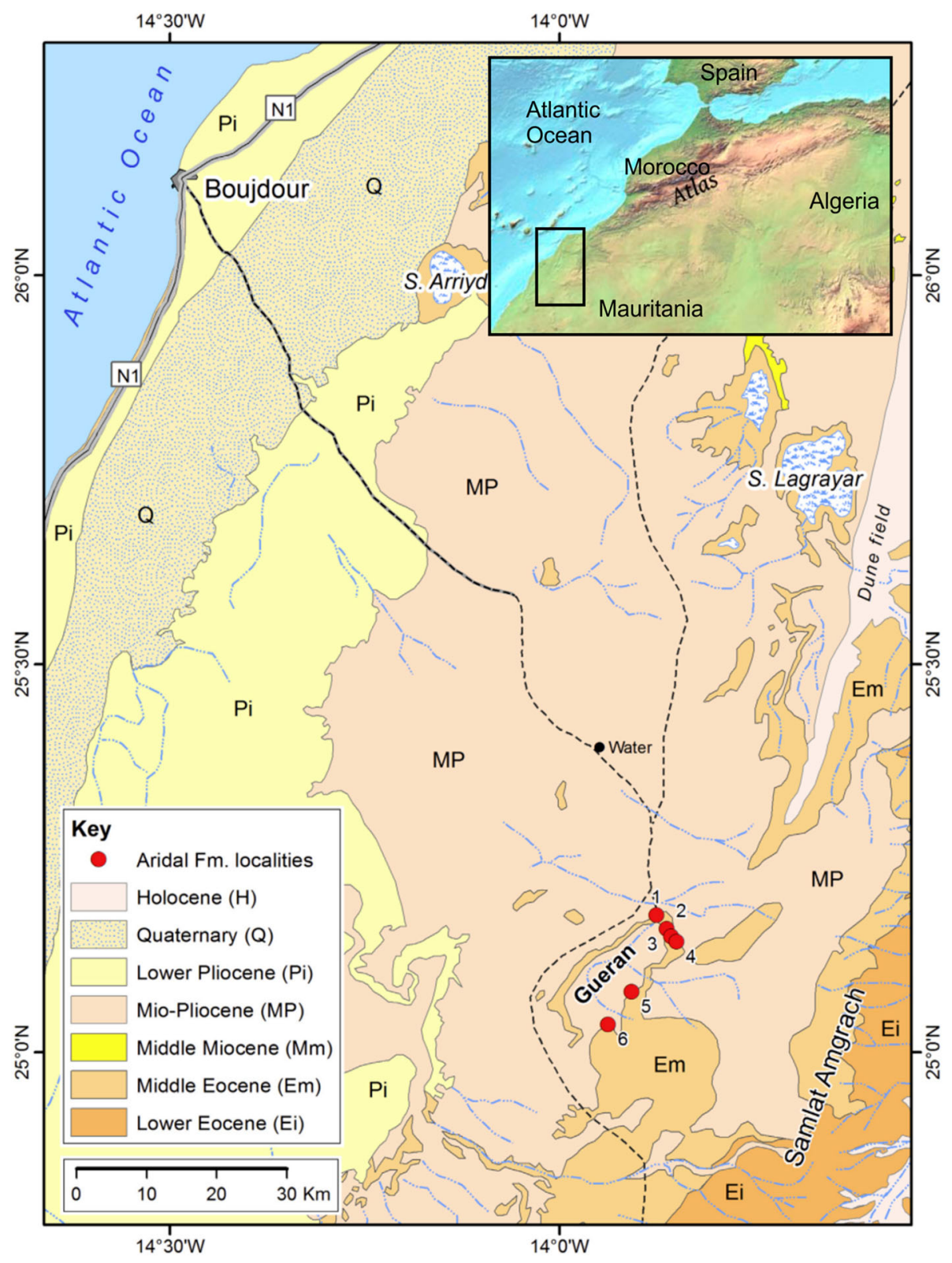

FIGURE 1. Geological map of the desert southeast of Boujdour in southwestern Morocco. Red dots mark sites yielding the remains described here and in Gingerich and Zouhri (2015) and Zouhri et al. (2018b). The geology is from Hollard et al. (1985), and the map is modified from Gingerich and Zouhri (2015). et al., 1982; Davison and Daily, 2010). The Gueran depression has been included in the Aridal Formation by Lindner and Querol (1971), a formation they regarded as Eocene in age.

The fossils described here come from a single sandstone layer that can be traced for many kilometers near the base of the escarpments surrounding the Gueran depression. The associated fauna is particularly diverse, with frequent selachian teeth (Otodus, Carcharocles), teleost vertebrae, turtle remains, and six species of archeocete whales (Gingerich and Zouhri, 2015; Zouhri et al., 2018a).

\section{SYSTEMATIC PALEONTOLOGY}

CROCODYLOMORPHA Walker, 1970 CROCODYLIFORMES Hay, 1930 (sensu Benton and Clark, 1988)
Material-FSAC BOUJ-355, fragment of a right dentary; FSAC BOUJ-406, posterior fragment of a left mandibular ramus.

Description - The fragment of a right dentary, FSAC BOUJ355 (Fig. 2A-D), has parallel medial and lateral margins and the right dentary is sutured with the left one in a long symphysis. The symphysis is slightly wider than high (1.5 times). A trace of the suture with the splenial is present on the posterodorsal surface of the symphysis. It preserves one complete alveolus and two poorly preserved ones. Its lateral and ventral sides are smooth and unornamented. The complete alveolus is much longer than wide. Its general outline could have been shorter than currently exposed. Therefore, the interalveolar distance was probably slightly longer than the alveolus diameter. The distance between left and right alveoli is relatively narrow, being 1.5 times larger than the width of an alveolus.

A posterior fragment of a left mandibular ramus, FSAC BOUJ406 (Fig. 2E, F), preserves four complete and two incomplete 


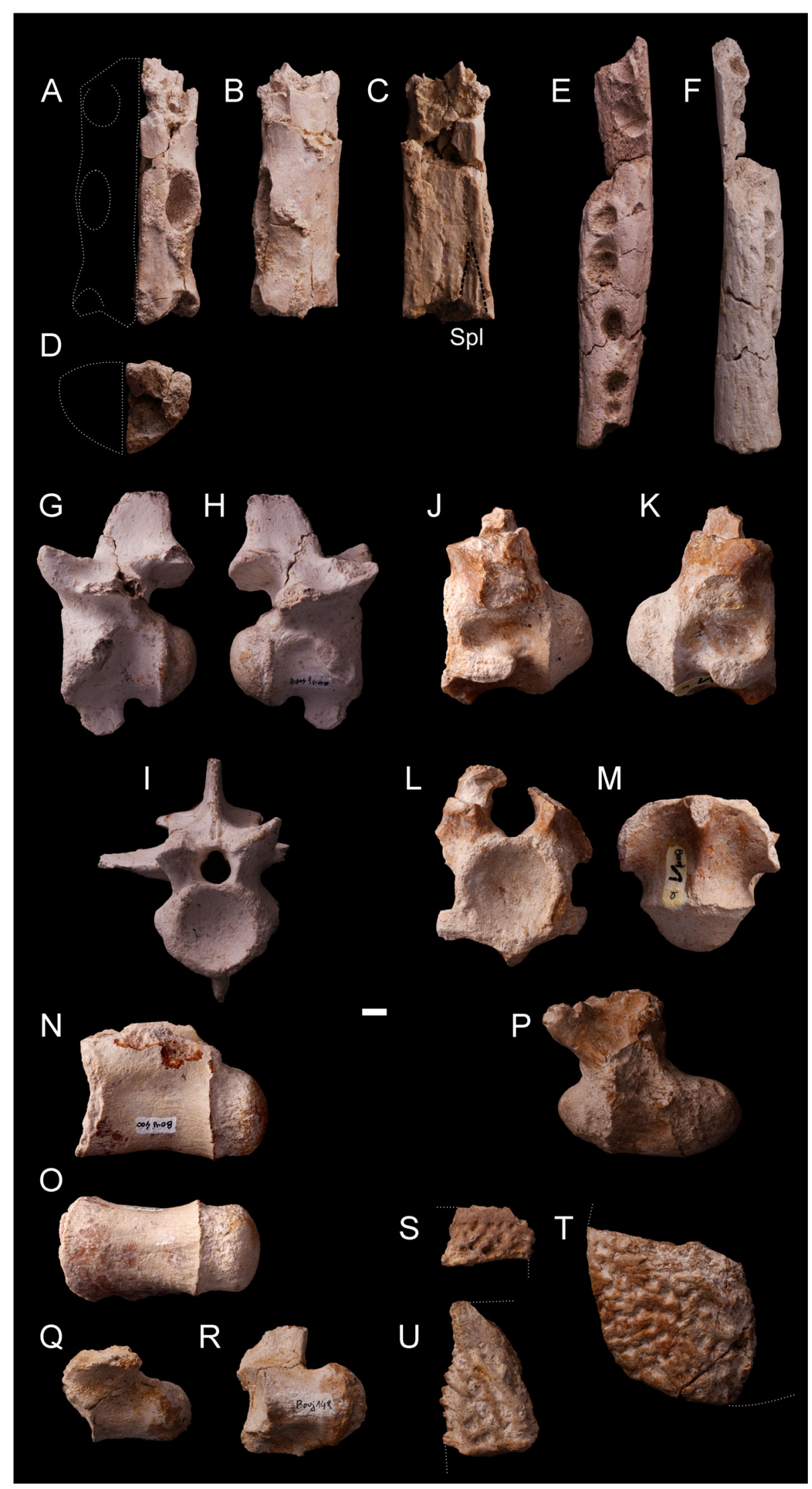

FIGURE 2. Crocodylian indet. from Gueran, Morocco. A-D, FSAC BOUJ-355, right dentary in $\mathbf{A}$, dorsal, $\mathbf{B}$, lateral, $\mathbf{C}$, medial, and D, posterior views. E-F, FSAC BOUJ-406, posterior fragment of a left mandibular ramus in $\mathbf{E}$, dorsal and F, lateral views. G-I, FSAC BOUJ410 , ninth cervical vertebra in $\mathbf{G}$, left lateral, $\mathbf{H}$, right lateral, and $\mathbf{I}$, anterior views. $\mathbf{J}-\mathbf{M}$, FSAC BOUJ-1b, anterior? cervical vertebra in $\mathbf{J}$, left lateral, $\mathbf{K}$, right lateral, $\mathbf{L}$, anterior, and $\mathbf{M}$, ventral views. N-O, FSAC BOUJ-400, posterior dorsal vertebra in $\mathbf{N}$, left lateral and $\mathbf{O}$, ventral views. P, FSAC BOUJ-1a, first caudal vertebra in left lateral view. Q-R, FSAC BOUJ-124, caudal vertebra in $\mathbf{Q}$, left lateral and $\mathbf{R}$, ventral views. S, FSAC BOUJ-94, osteoderm in dorsal view. T-U, FSAC BOUJ-96, T, posterior and $\mathbf{U}$, lateral portions of a dorsal osteoderm in dorsal view. Abbreviation: Spl, splenial. Scale bar equals $1 \mathrm{~cm}$. 
alveoli. Their size decreases from front to back; the second one seems to be much longer because the occlusal pits just anterior and posterior to the maxillary teeth are confluent with the alveolus. The fragment is particularly low in lateral view, and its lateral and ventral surfaces are ornamented with rare and spaced pits and furrows.

\section{CROCODYLIA Gmelin, 1789 (sensu Benton and Clark,} 1988)

Material-FSAC BOUJ-410, a ninth cervical vertebra; FSAC BOUJ-1b, an anterior? cervical vertebra; FSAC BOUJ-400, a posterior dorsal vertebra; FSAC BOUJ-1a, a first caudal vertebra; FSAC BOUJ-124, a caudal vertebra; FSAC BOUJ-96, two fragments of large dorsal osteoderms; FSAC BOUJ-94, a fragment of an osteoderm.

Description-Several isolated postcranial remains have been found. The best-preserved vertebra has a massive centrum (Fig. 2G-I). It is procoelous and bears a nearly complete high hypapophysis in its anterior half. The parapophysis is posteroventrally oriented and located in the anterior portion of the centrum and level with its center relative to its height. The diapophysis is high, level with the prezygapophysis. The neural spine is damaged, lacking most of its dorsal portion. Its base is long, being three-quarters the length of the centrum body (excluding the posterior condyle). Its anterior margin is curved. The suture between the centrum and the neural arch is visible and passes far ventral to the diapophysis and dorsal to the parapophysis. These relationships and the high position of the parapophysis on the lateral surface of the neural arch suggest that this vertebra would be the last cervical (ninth) or the first dorsal (10th), but the anteroposteriorly short neural spine suggests that it is more probably the last cervical than the first dorsal. Several other isolated vertebrae have been found.

Specimen FSAC BOUJ-1b is a cervical vertebra (Fig. 2J-M). The centrum is procoelous and bears a parapophysis oriented laterally and located in its anterior lateral portion. The ventral surface of the centrum bears a robust and short tubercle. The neural arch is considerably damaged, but its diapophysis is visible on its lateral side, the centrum participating in its ventral portion. Due to the shortness of the hypapophysis and the low positions of the diapophysis and parapophysis, this cervical vertebra is probably an anterior one, anterior to the seventh, but its exact location cannot be determined.

Specimen FSAC BOUJ-400 is an isolated procoelous centrum lacking most of the neural arch (Fig. 2N, O). The suture between the centrum and the neural arch is high on the centrum, and thus the transverse process, preserved by its base, is more dorsal than the dorsal margin of the centrum. This specimen is thus a dorsal vertebra, and the absence of a hypapophysis suggests that it was from the posterior part of the trunk.

Specimen FSAC BOUJ-1a is a biconvex centrum that preserves a part of its neural arch (Fig. 2P). This shape is typical of the first caudal vertebra in eusuchians. The anterior convexity is smaller than the posterior one, and the centrum body is relatively short. The broken transverse process is on the dorsal portion of the centrum, and the centrum-neural arch suture passes ventral to it. The neural spine is not preserved, and the prezygapophysis extends far anterior to the centrum body.

Specimen FSAC BOUJ-124 is a procoelous centrum bearing part of the transverse process (Fig. 2Q, R). The centrum is long and low, and the anterior margin of the transverse process extends far anterior to the anteroventral margin of the centrum. This anterior margin is thus strongly anterodorsally inclined. Due to its shape, this vertebra is a caudal.

Some osteoderm fragments are preserved. Specimen FSAC BOUJ-96 is large, thick, and densely ornamented with deep pits (Fig. 2 T). No trace of a dorsal keel is visible. Its anterior portion is lacking, so the exact shape of its outline cannot be completely evaluated. It articulated by means of a suture with a more medial osteoderm of the same transverse row. No trace of a suture is visible on the lateral side, so the osteoderm was probably the lateral-most of the row. Specimen FSAC BOUJ-94 is a small fragment of osteoderm with the same ornamentation pattern as in FSAC BOUJ-96, but with an anterior smooth surface for articulation with the preceding osteoderm (Fig. 2U). Specimen FSAC BOUJ-94 is a left portion of a dorsal osteoderm (Fig. 2S). It is dorsally ornamented with deep pits and preserves an anterior smooth surface. Its medial margin is sutured with the adjacent osteoderm. Its medial margin is not straight but sigmoid.

\section{GAVIALOIDEA Hay, 1930 (sensu Brochu, 1999)}

Material-FSAC BOUJ-403, FSAC BOUJ-404, and FSAC BOUJ-401, anterior to posterior portions of a left maxilla; FSAC BOUJ-407, posterior portion of a left maxilla; FSAC BOUJ-402, mid-portion of a right maxilla. All these specimens are from the same individual. FSAC BOUJ-405, portion of a left dentary.

Description - The preserved portion of the maxillae allows a reconstruction of the shape of the snout (Fig. 3E-G). It is long, slender, and wider than high. Its dorsolateral surface is ornamented with anteroposteriorly oriented shallow ridges and furrows. The nasals are not preserved, but the medial distance separating the maxillae dorsally suggests that they were narrow between the maxillae, reaching the premaxillae dorsally. The posterior portion of the premaxilla-maxilla suture is preserved and suggests that the posterodorsal premaxillary posterior process reached at least the second preserved maxillary alveolus. The palate also preserves the premaxilla-maxilla suture which exceeds posteriorly the level of the second preserved alveolus (Fig. 3E). The distance between anterior left and right teeth is more than 4.5 times the width of an alveolus. The number of preserved alveoli is 16 in the left maxilla, but because several parts are lacking the number was higher. Anterior to the first preserved tooth, the palatal portion of the maxilla is prolonged by a long lamina, excluding the presence of the premaxilla-maxilla lateral suture, but suggesting the probable presence of a tooth anterior to the preserved one before the premaxillary-maxillary suture. The posterior-most portion of the maxilla bears three teeth, and their difference in size from the posterior-most alveoli of the preserved more anterior portion suggests that at least two alveoli are lacking. Therefore, the number of maxillary teeth can be estimated to be 19 or 20 teeth per maxilla. The palate surface is lower than the tooth row such that the tooth row is underlined. The diameter of the alveoli and the interalveolar distance are nearly constant along the tooth row, the intervals being of nearly the same size as the diameters of the adjacent alveoli. The lateral margin of the maxilla is marked with shallow grooves visible in dorsal view for the occlusion of dentary teeth.

Specimen FSAC BOUJ-407 is a fragment of the posterior portion of the left maxilla. It preserves on its medial surface the trace of the suture with the ectopterygoid. The ectopterygoid reaches the level of the penultimate maxillary tooth. The dorsolateral surface of the same fragment preserves a trace of the maxilla-jugal suture. Therefore, the maxilla extends well posterior to the ultimate tooth. Several teeth are preserved in place (Fig. $3 \mathrm{H}-\mathrm{J}$ ). They are moderately long, circular in cross-section, and their surfaces are smooth, bearing anterior and posterior carinae. The posterior teeth are laterodorsally oriented, whereas those from the midlength of the maxillary are much more anterodorsally oriented, such that the carinae are located more medially and laterally than anteriorly and posteriorly compared with the snout orientation (Fig. 3E, F). 


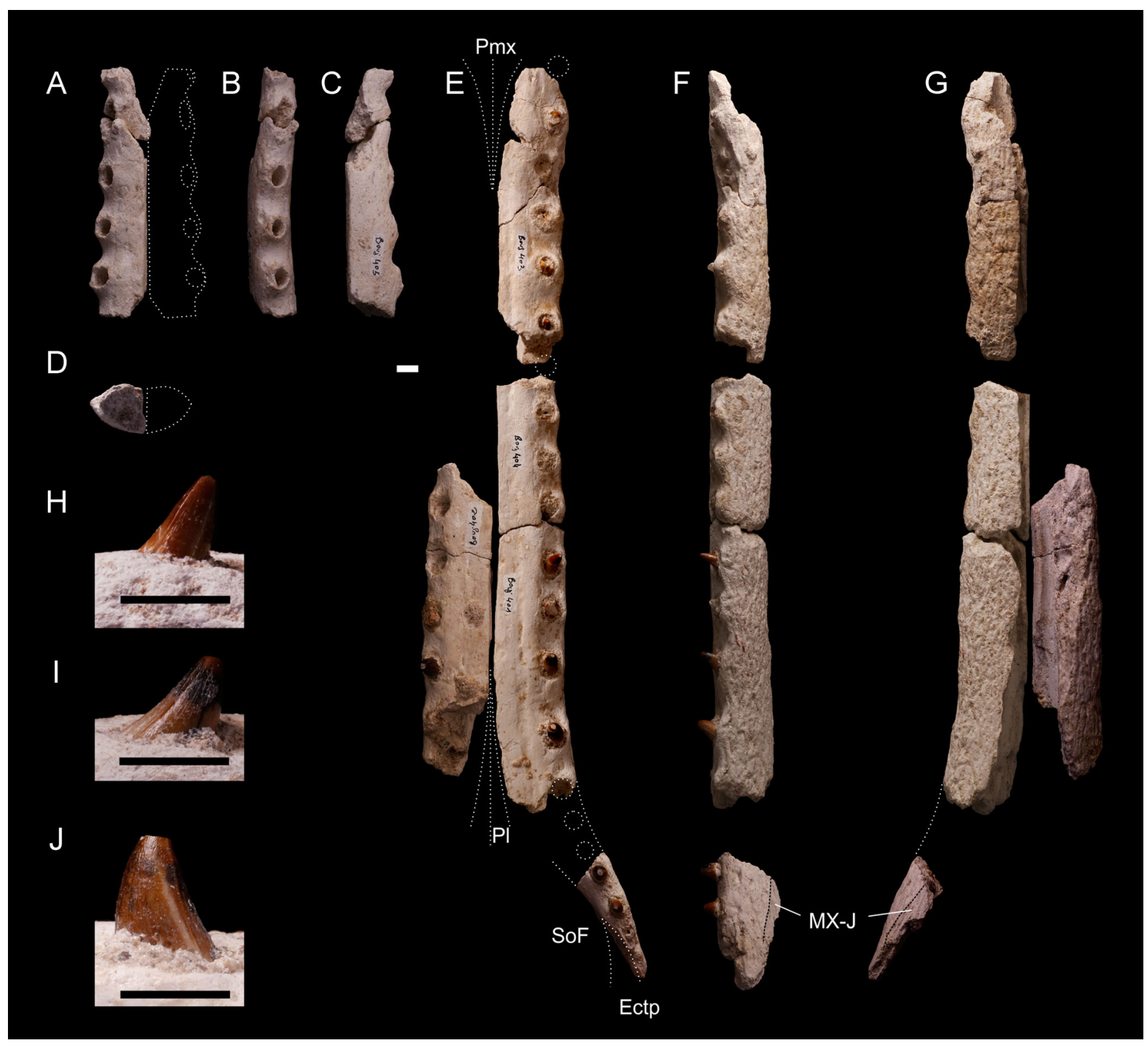

FIGURE 3. Gavialoid remains from Gueran, Morocco. A-D, FSAC BOUJ-405, portion of a left dentary in A, dorsal, B, lateral, C, ventral, and D, posterior views. E-G, FSAC BOUJ-401, FSAC BOUJ-402, FSAC BOUJ-403, FSAC BOUJ-404, and FSAC BOUJ-407, fragmentary snout in E, ventral, F, left lateral, and G, dorsal views. H, FSAC BOUJ-401, 11th left maxillary tooth in lateral view. I, FSAC BOUJ-401, 13th left maxillary tooth in lateral view. J, FSAC BOUJ-402, 13th right maxillary tooth in lateral view. Abbreviations: Ectp, ectopterygoid; MX-J, maxillojugal contact; PI, palatine; Pmx, premaxilla; SoF, suborbital fenestra. Scale bars equal $1 \mathrm{~cm}$.

Specimen FSAC BOUJ-405 consists of a left portion of a dentary and comprises four complete alveoli and the posterior margin of a fifth (Fig. 3A-D). The lateral margin of the preserved mandible is parallel to the medial margin that is sutured with the right dentary in the symphysis. The lateral margin of the dentary is marked by deep natural notches that indicate occlusal grooves for the maxillary teeth. The mandible is more than twice as wide as it is high, and the symphysis was probably very long. The distance between anterior left and right teeth is more than 4.5 times the width of an alveolus. The preserved alveoli are of nearly the same size, and the interalveolar distance is slightly longer than the alveolus diameter. The lateral and ventral surfaces of the mandible are smooth and unornamented.

\section{DISCUSSION}

\section{Taxonomic Affinities}

All vertebrae found in Gueran are procoelous (Fig. 2G-R), suggesting that all specimens found in this locality are probably eusuchians (Salisbury et al., 2006) and pertain to one or several species.

All skull and mandibular fragments pertain to longirostrine specimens. The skull remains and FSAC BOUJ-405 have identical morphological characteristics (Fig. 3). They have the same alveolus shape, the interalveolar distance is nearly equal to the alveolus diameter, the distance between the left and right tooth rows is 4.5 times the width of an alveolus, and the margins of the alveoli are not at the same level as the surface between the 
tooth rows. Therefore, we consider that they probably belong to the same species. Two groups of longirostrine crocodylians have been described during the late Eocene: the gavialoids and the tomistomines (Brochu, 2003). In our material, the number of teeth is high, with at least 19 or 20 maxillary teeth, a number only found in gavialoids, in which this number is from 16 to 30 (Müller, 1927; Sill, 1970), whereas it is from 13 to 16 in tomistomines (Jouve et al., 2014). The teeth are relatively short for longirostrine forms, but their apex is sharp. Their peculiar orientation, more anterodorsal than laterodorsal, is found in gavialoids only, such as in Thoracosaurus isorhynchus (Pomel, 1847), or the extant Gavialis gangeticus (S.J., pers. observ.), but in the latter the teeth are long and slender. In tomistomines, the teeth are more massive with a blunter apex, such as in Maroccosuchus zennaroi and Tomistoma lusitanica (Vianna and Moraes, 1945), or long and slender with a sharp apex, such as in 'Tomistoma' cairense Müller, 1927, and Dollosuchoides densmorei Brochu, 2007 (Jouve et al., 2014). Even if the premaxillae are not preserved, the premaxillary-maxillary suture on the palate exceeds posteriorly the level of the second preserved maxillary tooth, which is probably the third. This character is a gavialoid apomorphy (Jouve et al., 2008). Therefore, the skull fragments from Gueran pertain to a gavialoid, but the material is too poor to provide a more precise identification. Another posterior left fragment of a mandible (FSAC BOUJ-406) may be related to the same species with its small and regularly spaced rounded alveoli (Fig. 2E, F), but it is too limited to be clearly attributed.

The number of teeth, their robust shape, and the unkeeled osteoderms are characters congruent with those found in Maastrichtian-Paleocene basal gavialoids such as Thoracosaurus isorhynchus (S.J., pers. observ.) and Eosuchus spp. (Brochu, 2006; S.J., pers. observ.). Nevertheless, Eosuchus differs from the Gueran gavialoid in having a lateral margin of the maxillae that curves throughout its length and short interalveolar distances. Eogavialis africanum (Andrews, 1901) also has unkeeled osteoderms, comparable skull size, tooth number and shape, and distance between them that strongly resemble the conditions observed in the Gueran gavialoid. Its maxillary tooth row is also underlined by the medial palatal surface, which is lower throughout its length as in the Gueran gavialoid, whereas this is only observed in the posterior portion of the palate in T. isorhynchus (S.J., pers. observ.).

Compared with gavialoid remains from the coeval Dor-ElTalha (Bartonian of southern Libya) (Llinas Agrasar, 2004), no clear differences can be noted. Unfortunately, the remains are too poor to provide a detailed comparison.

The postcranial material bears few diagnostic characters, and because the material from younger levels found in Ad-Dakhla (Morocco) is formed mostly by this kind of remains (Zouhri et al., 2018a), clear comparisons are difficult. Nevertheless, the few teeth found in Ad-Dakhla with their robust shape resemble those found in the gavialoid from Gueran.

Therefore, although the Gueran gavialoid is fragmentary, comparison suggests affinities with E. africanum. The PriabonianRupelian age of this species, like its North African origin (Egypt), is congruent with this hypothesis.

A second mandibular morphotype has been found in Gueran. Specimen FSAC BOUJ-355 differs from other mandibular and maxillary fragments. Its symphysis is 1.5 times wider than high, whereas the symphysis is twice as wide in FSAC BOUJ-405, the preserved alveolus is larger, the distance between the left and right tooth rows is narrower, and the margins of the alveoli are almost level with the surface of the dentary between the left and right rows. Due to the shape of this symphysis, it cannot be attributed to a gavialoid. The distance between the left and right tooth rows is particularly narrow, a character never found in any gavialoid and tomistomine. This shape of mandible is found in longirostrine dyrosaurids (Jouve, 2007), neosuchians with amphicoelous vertebrae. Even if no amphicoelous vertebra has been found in Gueran, it cannot be excluded that this mandibular fragment pertains to a dyrosaurid, because the last members of this group are known until the Lutetian in Africa and the Bartonian in Burma (Buffetaut, 1978). Awaiting better-preserved material, this specimen is considered to be Crocodyliformes indet.

\section{Paleobiogeographic Implications}

Eocene and Oligocene gavialoids are particularly scarce, with Eogavialis africanum from the Priabonian and Rupelian Fayum beds, Egypt (Müller, 1927), fragmentary remains from the Priabonian of Ad-Dakhla, Morocco (Zouhri et al., 2017), and the Bartonian of Dor-El-Talha, southern Libya (Llinas Agrasar, 2004), and 'Gavialis' dixoni Owen, 1850, from the lower-middle Eocene of England and now considered to be a nomen dubium (Brochu, 2007) (Appendix S1 in Supplemental Data 1). The Moroccan gavialoids are the westernmost known gavialoids from the Eocene. These discoveries could be of particular importance, because the earliest known South American gavialoids are from the latest Eocene (Salas-Gismondi et al., 2016). The Eocene and the Oligocene are particularly important in the dispersal of gavialoids because the split between South American and Asian clades of gavialoids could date from the late Eocene-Oligocene (Salas-Gismondi et al., 2016). Moreover, phylogenetic relationships suggest strong connections between basal South American gavialoids, Eogavialis africanum, and the Moroccan Argochampsa krebsi Hua and Jouve, 2004. Whereas Jouve (2016) considered Aktiogavialis puertoricensis Vélez-Juarbe et al., 2007, from Puerto Rico to be closely related to E. africanum and Argochampsa krebsi to be sister taxon to Asian and other South American gavialoids, Salas-Gismondi et al. (2016) found that A. krebsi forms a clade with A. puertoricensis and that E. africanum is closely related to this clade plus Asian and other South American gavialoids. Therefore, although an uncertainty exists in the relationships between the forms that are basal to the Asian-South American clade, and in the origin of the diversification of gavialoids in both continents, a clear relationship exists between Egyptian, Moroccan, and South American gavialoids. In this context, Morocco could have been the African platform for the migration to South America. More material of the Gueran gavialoid could allow reconstruction of its phylogenetic relationships and clarification of the origin and date of the dispersal route of gavialoids to South America.

\section{Paleogene Climate, Sea level, and Longirostrine Crocodylian Evolution}

Crocodylomorphs are environmentally sensitive, and their distribution is strongly correlated with climatic constraints, driving their latitudinal distribution (Markwick, 1998a, 1998b; Carvalho et al., 2010; Martin et al., 2014; Mannion et al., 2015). The latitudinal distribution of the Peri-Tethys longirostrine crocodylians, gavialoids, and tomistomines varies through the Eocene and Oligocene (Fig. 4C-H; Appendix S1 in Supplemental Data 1). They are present in the northern part of the Northern Hemisphere, such as in England, Belgium, Germany, and Ukraine during the Ypresian and Lutetian (Fig. 4C, D) and in North Africa and not far away from the northern margin of the Tethys in Europe (southern France and northern Italy) during the Bartonian (Fig. 4E). The distribution of tomistomines seems also to differ between early and late Lutetian: early Lutetian forms are present in northern Europe, whereas late Lutetian tomistomines are restricted to southern Europe as during the Bartonian (Jouve, 2016). Longirostrine crocodylians are present only in North Africa and absent from the north Tethyan area during the Priabonian and Rupelian (Fig. 4F, G). Numerous localities with 


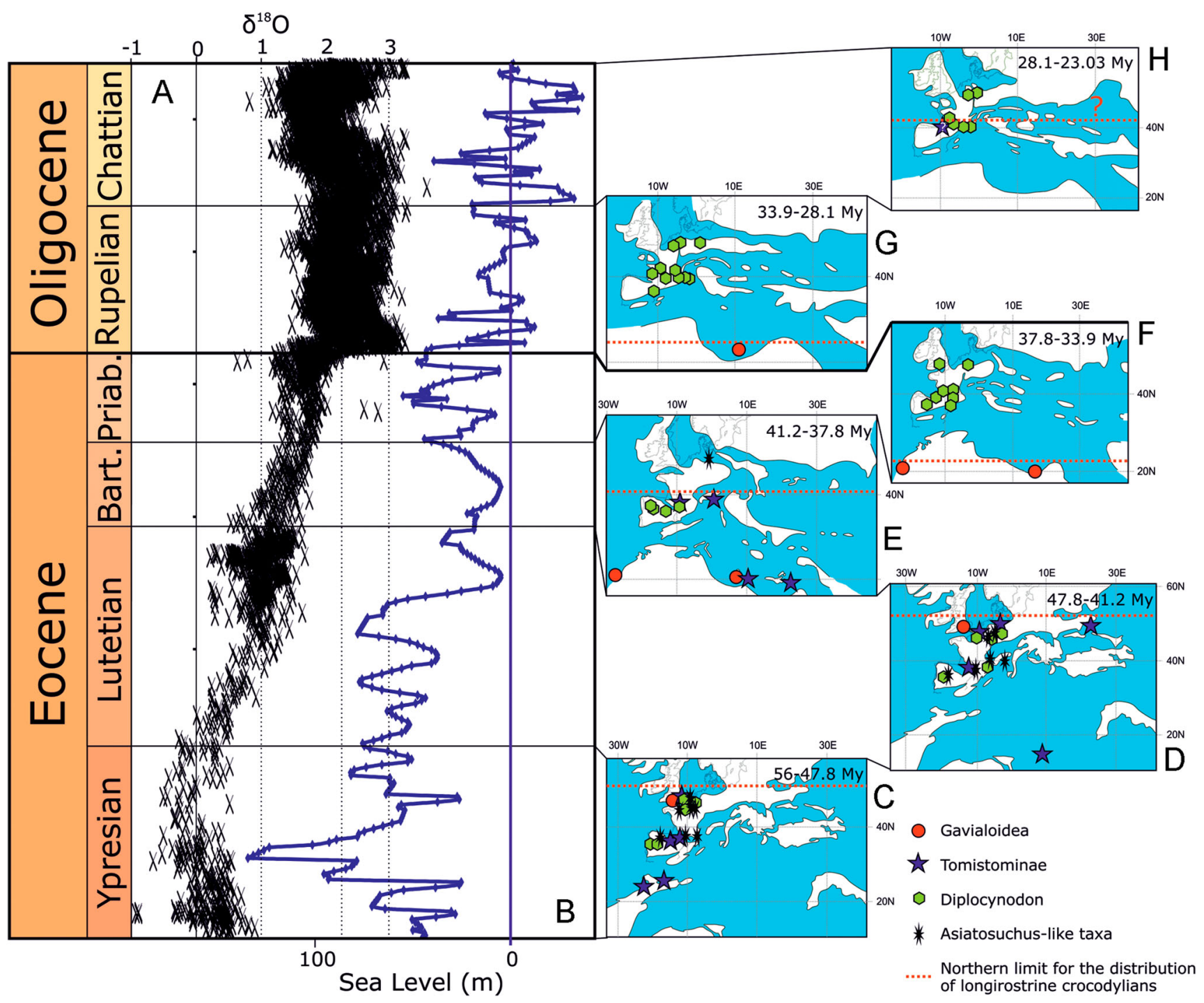

FIGURE 4. Comparison of the evolution of the distribution between longirostrine crocodylians, Diplocynodon, and Asiatosuchus-like crocodylians with the evolution of $\mathbf{A}$, paleotemperature $\left(\delta^{18} \mathrm{O}\right)$ and $\mathbf{B}$, sea level through the Eocene and the Oligocene. C, Ypresian; D, Lutetian; E, Bartonian; F, Priabonian; G, Rupelian; H, Chattian. Sea level data are from Miller et al. (2005), and $\delta^{18} \mathrm{O}$ data are from Zachos et al. (2008). Maps redrawn from Jouve (2016) and Rögl (1999). For diversity data, see Appendix S1 in Supplementary Data 1. For $\delta^{18}$ O and sea level data, see Appendix S2 in Supplementary Data 2.

Diplocynodon remains have been found in Europe during the same periods, suggesting that the absence of longirostrine crocodylians from the north Tethyan area is not related to sampling on this continent (Fig. 4G, H). Bartonian-Oligocene gavialoids are absent from the northern margin of the Tethys area, whereas tomistomines are absent from Europe and the Peri-Tethys area from the Priabonian to at least the late Oligocene (Fig. 4). A tomistomine has been described in the Chattian based on a unique tooth of doubtful assignment (Antunes and Cahuzac, 1999). This progressive disappearance of gavialoids and tomistomines from Europe, from north to south, may be correlated with the constant climatic deterioration, illustrated by the variations in the $\delta^{18} \mathrm{O}$ value (Fig. 4A) and oscillations of sea level (Fig. 4B) (Miller et al., 2005; Zachos et al., 2008) (Appendix S2 in Supplemental Data 2). Variation in latitudinal range according to climatic variations has been observed in the Japanese tomistomine Toyotamaphimeia machikanensis (Iijima et al., 2018) and was suggested for European Eocene tomistomines (Jouve, 2016).
The same has been observed in Alligator mississippiensis, and the presence of this species has been tentatively used as a climatic proxy to reconstruct the climatic and environmental Neogene variations in the central Great Plains (Whiting, 2016). Possible variation of latitudinal distribution according to climatic fluctuations has also been suggested for the late Eocene-early Miocene alligatoroid Diplocynodon. Some authors suggested a possible southward shift of this genus according to the Oligocene and Miocene climatic deterioration (Böhme, 2003; Martin, 2010), but the presence of Diplocynodon remains in Belgium and Germany during the lower Oligocene contradicts this theory for that period (Smith, 2003; Lange-Badré and Böhme, 2005; Karl, 2007). Compared with the distribution of gavialoids and tomistomines, European Diplocynodon has a large latitudinal distribution, from Spain to England. No significant variation is observed through the Eocene-Oligocene, even during the earliest Oligocene, the period with the lowest temperatures (Fig. 4). Differences exist in the environments occupied by Diplocynodon 
and longirostrine crocodylians. All Diplocynodon remains were found in freshwater environments, whereas most of the Paleogene tomistomines and gavialoids are marine forms. The sea level (Miller et al., 2005) has fluctuated considerably through the studied period, but it becomes drastically lower during the late Lutetian-Bartonian. Tomistomines are present in southern Europe during this period but absent during the following one (Priabonian), when the sea level is not so different. Moreover, Asiatosuchus-like taxa are also known in the early and middle Eocene in Europe, and if their presence is probable during the Bartonian they are completely absent later (Fig. 4). The extinction of Asiatosuchus-like taxa has been related to the climatic deterioration of the late Eocene (Vasse, 1992) and cannot be related to sea level. These taxa have been found in similar environments to that of Diplocynodon, and no environmental factors other than climate-sensitive differences can explain the difference in the survivorship between the taxa.

The difference in the distribution of longirostrine crocodylians and Diplocynodon may be partly explained by the difference in their marine and freshwater preferences. Freshwater environments were not impacted by sea level changes, but this cannot explain the difference between Diplocynodon and Asiatosuchus-like taxa. Climatic deterioration was probably the main factor that drove the latitudinal distribution and disappearance from high latitudes of longirostrine crocodylians. The sea level, which impacted all coastal marine environments without latitudinal differences, may be an aggravating factor and may have affected their diversity, which became lower in general, not only in the Peri-Tethys area.

These differences in distribution could be related to tolerance of a wider range of climatic conditions in Diplocynodon (Martin, 2010). Such differences are observed in extant species. Alligator mississippiensis occupies higher latitudes than any other extant crocodylian (Thorbjarnarson, 1992; Lance, 2003) and may be better adapted, physiologically and behaviorally, for survival in cooler conditions than other members of extant Crocodylia (e.g., Asa et al., 1998; Whiting, 2016). The sympatric American crocodile, Crocodylus acutus, which is restricted to the southern part of the distribution observed for A. mississippiensis, seems to have its northward expansion in southwestern Florida controlled by temperature (Kushlan and Mazzotti, 1989). Critical temperature is not known for C. acutus, but increased mortality has been suggested during a winter freeze in south Florida with a water temperature of 13 $14^{\circ} \mathrm{C}$ (Moler, 1991), far from the low temperatures easily supported by $A$. mississippiensis. Such differences in climatic tolerance could have existed during the Eocene-Oligocene between Diplocynodon and longirostrine crocodylians tomistomines, gavialoids, and Asiatosuchus-like taxa.

The transition between the end of the Eocene and the beginning of the Oligocene is marked by large-scale extinction and floral and faunal turnover, particularly in Europe (e.g., Stehlin, 1909; Houben et al., 2012; Goldner et al., 2014). The variation observed in longirostrine forms is not related to the 'Grande Coupure' but seems to be related to a longer event that began during the Lutetian. Eocene climatic deterioration, helped by sea level oscillations, impacted the marine longirostrine crocodylians in their distribution and caused extinction of some other crocodylians restricted to Europe, such as Asiatosuchus-like taxa. A late Eocene-Oligocene decline in crocodylian diversity was previously statistically suggested (Mannion et al., 2015), but a southward migration of the northern limit in the distribution of some crocodylian groups is highlighted here as differential tolerance in the range of climatic conditions.

\section{CONCLUSIONS}

At least two species are present in Gueran, a gavialoid and a second longirostrine form of indeterminate affinities. This diversity is identical to that is observed later in late Eocene Egyptian and Libyan localities. Unfortunately, the remains are too fragmentary to determine their precise affinities. Nevertheless, the presence of a Bartonian gavialoid in the west African margin is of particular interest, and better-preserved material allowing the reconstruction of the affinities of this species could provide important data on gavialoid dispersal to South America.

The analysis of the Eocene-Oligocene distribution of longirostrine crocodylians brings new information on their evolution and relationship to climatic variations and oceanic oscillations. Differences are observed in the distribution of the longirostrine crocodylians and Diplocynodon. Whereas gavialoid and tomistomine distribution decreases, that of Diplocynodon remains unchanged. Eocene climatic deterioration may have caused the southward migration of the northern limit in the distribution of some crocodylian groups, and the extinction of some other European crocodylians. Differential tolerance in the range of climatic conditions may explain the survivorship of Diplocynodon in Europe. This should be considered in future diversity analyses comparing climatic oscillations, and considering the crocodylians, and sometimes the Crocodylomorpha, as a homogeneous group. Such identification of climatic tolerance could also help to precisely use crocodylians as climatic proxies.

\section{ACKNOWLEDGMENTS}

S.J. thanks L. Steel (Natural History Museum, London) and M. Rabi and Z. Szentesi (both Hungarian Natural History Museum) for their help, hospitality, and access to collections and material. We are grateful to two anonymous reviewers for their comments and to S. Salisbury for the editing process. S.J. received support from the SYNTHESYS Project (www. synthesys.info), which is financed by the European Community Research Infrastructure Action under the FP7 'Capacities' Program (HU-TAF-4866; GB-TAF-3366). Fieldwork research was supported by GRANT \#9765-15 from the National Geographic Society.

\section{ORCID}

Stéphane Jouve (D) http://orcid.org/0000-0002-0420-8648

\section{LITERATURE CITED}

Andrews, C. W. 1901. Preliminary note on some recently discovered extinct vertebrates from Egypt. Geological Magazine 4:436-444.

Antunes, M. T., and B. Cahuzac. 1999. Crocodilian faunal renewal in the Upper Oligocene of Western Europe. Comptes Rendus de l'Académie des Sciences, Series IIA: Earth and Planetary Science 328:67-72.

Asa, C. S., G. D. London, R. R. Goellner, N. Haskell, G. Roberts, and C. Wilson. 1998. Thermoregulatory behavior of captive American alligators (Alligator mississippiensis). Journal of Herpetology 32:191197.

Bardet, N., E. Gheerbrant, A. Noubhani, H. Cappetta, S. Jouve, E. Bourdon, X. Pereda Suberbiola, N.-E. Jalil, P. Vincent, A. Houssaye, F. Solé, K. Houssaini Darif, S. Adnet, J.-C. Rage, F. de Lapparent de Broin, J. Sudre, B. Bouya, M. Amaghzaz, and S. Meslouh. 2017. Les Vertébrés des phosphates crétacés-paléogènes (72,1-47,8 Ma) du Maroc. Mémoire de la Société géologique de France 180:351-452.

Benton, M. J., and J. M. Clark. 1988. Archosaur phylogeny and the relationships of the Crocodilia; pp. 295-338 in M. J. Benton (ed.), The Phylogeny and Classification of the Tetrapods. Clarendon Press, Oxford, U.K.

Böhme, M. 2003. The Miocene Climatic Optimum: evidence from ectothermic vertebrates of Central Europe. Palaeogeography, Palaeoclimatology, Palaeoecology 195:389-401. 
Brochu, C. A. 1999. Phylogenetics, taxonomy, and historical biogeography of Alligatoroidea. Journal of Vertebrate Paleontology 19:9-100.

Brochu, C. A. 2003. Phylogenetic approaches toward crocodylian history. Annual Review of Earth and Planetary Sciences 31:357-397.

Brochu, C. A. 2006. Osteology and phylogenetic significance of Eosuchus minor (Marsh, 1870) new combination, a longirostrine crocodylian from the late Paleocene of North America. Journal of Paleontology 80:162-186.

Brochu, C. A. 2007. Systematics and taxonomy of Eocene tomistomine crocodylians from Britain and Northern Europe. Palaeontology 50:917-928.

Buffetaut, E. 1978. A dyrosaurid (Crocodylia, Mesosuchia) from the Upper Eocene of Burma. Neues Jahrbuch für Geologie und Paläontologie, Monatshefte 1978:273-281.

Carvalho, I. de S., Z. B. de Gasparini, L. Salgado, F. M. de Vasconcellos, and T. da S. Marinho. 2010. Climate's role in the distribution of the Cretaceous terrestrial Crocodyliformes throughout Gondwana. Palaeogeography, Palaeoclimatology, Palaeoecology 297:252-262.

Davison, I., and P. Dailly. 2010. Salt tectonics in the Cap Boujdour Area, Aaiun Basin, NW Africa. Marine and Petroleum Geology 27:435-441.

Gingerich, P. D., and S. Zouhri. 2015. New fauna of archaeocete whales (Mammalia, Cetacea) from the Bartonian middle Eocene of southern Morocco. Journal of African Earth Sciences 111:273-286.

Gmelin, J. F. 1789. Regnum animale, pp. 1033-1516 in G. E. Beer (ed.), Caroli a Linne Systema Naturae per Regna Tria Naturae, Secundum Classes, Ordines, Genera, Species, Cum Characteribus, Differentiis, Synonymis, Locis. Leipzig.

Goldner, A., N. Herold, and M. Huber. 2014. Antarctic glaciation caused ocean circulation changes at the Eocene-Oligocene transition. Nature 511:574-577.

Hay, O. P. 1930. Second Bibliography and Catalogue of the Fossil Vertebrata of North America. Carnegie Institute of Washington, Washington, D.C., 1074 pp.

Hollard, H., G., Choubert, G., Bronner, J., Marchand, and J. Sougy. 1985. Carte Géologique du Maroc, échelle 1:1,000,000. Service Carte Géologique Maroc, Rabat, Morocco, 2 sheets.

Houben, A. J. P., C.A., Van Mourik, A., Montanari, R., Coccioni, and H. Brinkhuis. 2012. The Eocene-Oligocene transition: changes in sealevel, temperature or both? Palaeogeography, Palaeoclimatology, Palaeoecology 335:75-83.

Hua, S., and S. Jouve. 2004. A primitive marine gavialoid from the Paleocene of Morocco. Journal of Vertebrate Paleontology 24:344-353.

Iijima, M., A. Momohara, Y. Kobayashi, S. Hayashi, T. Ikeda, H. Taruno, K. Watanabe, M. Tanimoto, and S. Furui. 2018. Toyotamaphimeia cf. machikanensis (Crocodylia, Tomistominae) from the Middle Pleistocene of Osaka, Japan, and crocodylian survivorship through the Pliocene-Pleistocene climatic oscillations. Palaeogeography, Palaeoclimatology, Palaeoecology 496:346-360.

Jonet, S., and G. Wouters. 1977. Maroccosuchus zennaroi, crocodilien Eusuchien nouveau des Phosphates du Maroc. Notes et Mémoires du Service Géologique du Maroc 38:177-202.

Jouve, S. 2007. Taxonomic revision of the dyrosaurid assemblage (Crocodyliformes, Mesoeucrocodylia) from the Palaeocene of the Iullemmeden basin, West Africa. Journal of Paleontology 81:163-175.

Jouve, S. 2016. A new basal tomistomine (Crocodylia, Crocodyloidea) from Issel (Middle Eocene; France): palaeobiogeography of basal tomistomines and palaeogeographic consequences. Zoological Journal of the Linnean Society 177:165-182.

Jouve, S., B. Bouya, M. Amaghzaz, and S. Meslouh. 2014. Maroccosuchus zennaroi (Crocodylia: Tomistominae) from the Eocene of Morocco: phylogenetic and palaeobiogeographical implications of the basalmost tomistomine. Journal of Systematic Palaeontology 12:1-25.

Jouve, S., N. Bardet, N.-E. Jalil, X. Pereda Suberbiola, B. Bouya, and M. Amaghzaz. 2008. The oldest African crocodylian: phylogeny, paleobiogeography, and differential survivorship of marine reptiles through the Cretaceous-Tertiary boundary. Journal of Vertebrate Paleontology 28:409-421.

Karl, H.-V. 2007. The fossil reptiles (Reptilia: Chelonii, Crocodylia) from the marine early Oligocene of the Weisselster Basin (central Germany: Saxonia). Studia Geologica Salmanticensia 43:25-66.

Kushlan, J. A., and F. J. Mazzotti. 1989. Historic and present distribution of the American crocodile in Florida. Journal of Herpetology 23:1-7.
Lance, V. A. 2003. Alligator physiology and life history: the importance of temperature. Experimental Gerontology 38:801-805.

Lange-Badré, B., and M. Böhme. 2005. Apterodon intermedius, sp. nov., a new European creodont mammal from MP22 of Espenhain (Germany). Annales de Paléontologie 91:311-328.

Lindner, A. W., and R. Querol. 1971. Mapa geologico del Sahara español 1:200,000. Instituto Geologico y Minero de España, Madrid, Spain.

Llinas Agrasar, E. 2004. Crocodilian remains from the Upper Eocene of Dor-El-Talha, Libya. Annales de Paléontologie 90:209-222.

Mannion, P. D., R. B. J. Benson, M. T. Carrano, J. P. Tennant, J. Judd, and R. J. Butler. 2015. Climate constrains the evolutionary history and biodiversity of crocodylians. Nature Communications 6:8438.

Markwick, P. J. 1998a. Crocodilian diversity in space and time: the role of the climate in paleoecology and its implication for understanding $\mathrm{K} /$ T extinctions. Paleobiology 24:470-497.

Markwick, P. J. 1998b. Fossil crocodilians as indicators of Late Cretaceous and Cenozoic climates: implications for using palaeontological data in reconstructing palaeoclimate. Palaeogeography, Palaeoclimatology, Palaeoecology 137:205-271.

Martin, J. E. 2010. A new species of Diplocynodon (Crocodylia, Alligatoroidea) from the Late Eocene of the Massif Central, France, and the evolution of the genus in the climatic context of the Late Palaeogene. Geological Magazine 147:596-610.

Martin, J. E., R. Amiot, C. Lécuyer, and M. J. Benton. 2014. Sea surface temperature contributes to marine crocodylomorph evolution. Nature Communications 5:4658. doi: 10.1038/ncomms5658.

Miller, K. G., M. A. Kominz, J. V. Browning, J. D. Wright, G. Mountain, M. E. Katz, P. J. Sugarman, B. S. Cramer, N. Christie-Blick, and S. F. Pakar. 2005. The Phanerozoic record of global sea-level change. Science 310:1293-1298.

Moler, P. E. 1991. American Crocodile Nest Survey and Monitoring. Final Report to Study No. 7533. Florida Game and Fresh Water Fish Commission, Bureau of Wildlife Research, Tallahassee, Florida, $10 \mathrm{pp}$.

Müller, L. 1927. Ergebnisse der Forschungsreisen Prof. E. Stromers in den Wüsten Ägyptens. V. Tertiäre Wirbeltiere. 1 Beiträge zur Kenntnis der Krokodilier des ägyptischen Tertiärs. Abhandlungen der Bayerische Akademie der Wissenschaften, MathematischNaturwissenschaftliche Abteilung 31(2):96 pp.

Pomel, A. 1847. Sur la flore et la faune fossiles du terrain pisolithique. Archives des Sciences Physiques et Naturelles 5:301-307.

Owen, R. D. 1850. Monograph on the Reptilia of the London Clay, and of the Bracklesham and Other Tertiary Beds, Part II: Crocodilia (Crocodilus, Etc.). The Palaeontological Society, London, 68 pp.

Ranke, U., U. von Rad, and G. Wissmann. 1982. Stratigraphy, facies and tectonic development of the on- and offshore Aaiun-Tarfaya Basin: a review; pp. 86-105 in U. von Rad, K. Hinz, M. Sarnthein, and E. Seibold (eds.), Geology of the Northwest African Continental Margin. Springer, Berlin, Germany.

Rögl, F. 1999. Mediterranean and Paratethys. Facts and hypotheses of an Oligocene to Miocene paleogeography (short overview). Geologica Carpathica 50:339-349.

Salas-Gismondi, R., J. J. Flynn, P. Baby, J. V. Tejada-Lara, J. Claude, and P.-O. Antoine. 2016. A new 13 million year old gavialoid crocodylian from proto-Amazonian mega-wetlands reveals parallel evolutionary trends in skull shape linked to longirostry. PLoS ONE 11:e0152453.

Salisbury, S. W., R. E. Molnar, E. Frey, and P. M. A. Willis. 2006. The origin of modern crocodyliforms: new evidence from the Cretaceous of Australia. Proceedings of the Royal Society B: Biological Sciences 273:2439-2448.

Sill, W. D. 1970. Nota preliminar sobre un nuevo gavial del Plioceno de Venezuela y una discusion de los Gaviales sudamericanos. Ameghiniana 7:151-159.

Smith, R. 2003. Les vertébrés terrestres de l'Oligocène inférieur de Belgique (Formation de Borgloon, MP 21): inventaire et interprétation des données actuelles. Colloquios de Paleontología $1: 647-657$.

Stehlin, H. G. 1909. Remarques sur les faunes de mammifères des couches éocènes et oligocènes du Bassin de Paris. Bulletin de la Société géologique de France, 4e série 9:488-520.

Thorbjarnarson, J. 1992. Crocodiles: An Action Plan for Their Conservation. International Union for Conservation of Nature (IUCN) Publication, Gland, Switzerland, 136pp. 
Vasse, D. 1992. Un crâne d'Asiatosuchus germanicus du Lutétien d'Issel (Aude), bilan sur le genre Asiatosuchus en Europe. Geobios 25:293-304.

Vélez-Juarbe, J., C. A. Brochu, and H. Santos. 2007. A gharial from the Oligocene of Puerto Rico: transoceanic dispersal in the history of a non-marine reptile. Proceedings of the Royal Society B: Biological Sciences 274:1245-1254.

Vianna, A., and A. Moraes. 1945. Sur un crâne de crocodile fossile découvert dans le Miocène de Lisbonne. Boletim da Sociedade Geologica de Portugal 4:161-170.

Walker, A. D. 1970. A revision of Jurassic reptile Hallopus victor (Marsh), with remarks on the classification of crocodiles. Philosophical Transactions of the Royal Society of London, B: Biological Sciences 257:323-372.

Whiting, E. 2016. Constraining Neogene temperature and precipitation histories in the Central Great Plains using the fossil record of Alligator. M.S. thesis, University of Nebraska Lincoln, Lincoln, Nebraska, 95 pp.
Zachos, J. C., G. R. Dickens, and R. E. Zeebe. 2008. An early Cenozoic perspective on greenhouse warming and carbon-cycle dynamics. Nature 451:279-283.

Zouhri, S., B. Khalloufi, E. Bourdon, F. de Lapparent de Broin, J.-C. Rage, L. M'HaïDrat, P. D. Gingerich, and N. Elboudali. 2018a. Marine vertebrate fauna from the late Eocene Samlat Formation of Ad-Dakhla, southwestern Morocco. Geological Magazine 155:1596-1620.

Zouhri, S., P. Gingerich, S. Adnet, E. Bourdon, S. Jouve, B. Khalloufi, A. Amane, N. Elboudali, J.-C. Rage, F. de Lapparent de Broin, A. Kaoukaya, and S. Sebti. 2018b. Middle Eocene vertebrates from the sabkha of Gueran, Atlantic coastal basin, Saharan Morocco, and their peri-African correlations. Comptes Rendus Geoscience 350:310-318.

Submitted August 28, 2018; revisions received January 21, 2019; accepted April 24, 2019.

Handling editor: Steven Salisbury. 